\title{
Cross-Linked Enzyme Aggregates and Their Application in Enzymatic Pretreatment of Microalgae: Comparison Between CLEAs and Combi-CLEAs
}

\section{OPEN ACCESS}

Edited by:

Javier Rocha Martín,

Institute of Catalysis and

Petrochemistry (ICP), Spain

Reviewed by:

Nadia Guajardo,

Metropolitan University of Technology,

Chile

Meryam Sardar

Jamia Millia Islamia, India

Manuela Poletto Klein,

Federal University of Health Sciences

of Porto Alegre, Brazil

*Correspondence:

Paz García-García

mariap.garcia@uam.es

Francisco Javier Señoráns

javier.senorans@uam.es

Specialty section:

This article was submitted to Industrial Biotechnology,

a section of the journal

Frontiers in Bioengineering and

Biotechnology

Received: 13 October 2021 Accepted: 08 November 2021

Published: 09 December 2021

Citation:

Blanco-Llamero C, García-García P and Señoráns FJ (2021) Cross-Linked

Enzyme Aggregates and Their

Application in Enzymatic Pretreatment of Microalgae: Comparison Between

CLEAs and Combi-CLEAs.

Front. Bioeng. Biotechnol. 9:794672.

doi: 10.3389/fbioe.2021.794672

\author{
Cristina Blanco-Llamero, Paz García-García * and Francisco Javier Señoráns * \\ Healthy Lipids Group, Departmental Section of Food Sciences, Faculty of Sciences, Universidad Autónoma de Madrid, Madrid, \\ Spain
}

Carrier-free immobilization is a key process to develop efficient biocatalysts able to catalyze the cell wall degradation in microalgae where the traditional solid supports cannot penetrate. Thus, the insolubilization of commercial Celluclast ${ }^{\circledR}$, Alcalase ${ }^{\circledR}$, and Viscozyme $^{\circledR}$ enzymes by carrier-free immobilization and their application in microalgae pretreatment was investigated. In this study, different precipitants at different ratios (ethanol, acetone, and polyethylene glycol 4000) were tested in the first part of the method, to establish the precipitation conditions. The screening of the best precipitant is needed as it depends on the nature of the enzyme. The best results were studied in terms of immobilization yield, thermal stability, and residual activity and were analyzed using scanning electron microscopy. Moreover, a novel strategy was intended including the three enzymes (combi-CLEAs) to catalyze the enzymatic degradation of Nannochloropsis gaditana microalgal cell wall in one pot. The carrier-free immobilized derivatives were 10 times more stable compared to soluble enzymes under the same. At the best conditions showed its usefulness in the pretreatment of microalgae combined with ultrasounds, facilitating the cell disruption and lipid recovery. The results obtained suggested the powerful application of these robust biocatalysts with great catalytic properties on novel and sustainable biomass such as microalgae to achieve costeffective and green process to extract valuable bioactive compounds.

Keywords: CLEAs, combi-CLEAs, immobilization, microalgae, enzymatic pretreatment, Viscozyme ${ }^{\circledR}$, Alcalase ${ }^{\circledR}$, Celluclast $^{\circledR}$

\section{INTRODUCTION}

Nowadays, microalgae have gained attention as an alternative biomass due to a wide range of characteristics that make them an interesting biomass source. Among these, it is interesting to highlight their ability to rapidly accumulate important amounts of added value components. In addition, their cultivation does not require arable lands or pure water; indeed, they are able to grow in wastewater and in bioreactors, which make microalgae a promising and environment-friendly source of bioactive compounds such as lipids, carotenoids, and proteins. Moreover, the composition of microalgae highly varies among the different species, which make them more versatile. On its own, 
Nannochloropsis gaditana is described as a microalga able to produce important amounts of lipids, including polar lipids, omega-3 polyunsaturated fatty acids, and carotenoids such as carotenes and xanthophylls, which have benefits for human health widely recognized (Yen et al., 2013; Gong and Bassi, 2016; Castejón et al., 2018; Castejón and Señoráns, 2019; Punia et al., 2019; Zhang et al., 2019; Castejón and Señoráns, 2020; Katiyar and Arora, 2020; Señoráns et al., 2020; BlancoLlamero and Señoráns, 2021).

Regarding extraction step, the most critical point is usually the selection of an appropriate extraction technique due to the presence of a dense and firm cell wall in microalgae, which difficult the extraction of bioactive compounds from the cells. $N$. gaditana cell wall contains mainly proteins and other biopolymers such as cellulose or pectin, among others. Thus, the cell wall must be properly disrupted to efficiently recover intracellular bioactive compounds (Blanco-Llamero et al., 2021). Several methods for cell disruption could be applied. Enzymatic digestion before extraction facilitates both lipid extraction and downstream process of microalga biomass. Weakened cell walls reduce solvent and energy inputs needed for extraction. Because the microalgae cell wall includes different fibers and proteins, an enzymatic cocktail with different hydrolytic activities like carbohydrases and proteases should be applied for this purpose. Thus, the use of enzymes has demonstrated to facilitate the hydrolysis of microalgae cell walls, which could be increased if the enzymes are combined between each other and with other physical disruption methods, obtaining increased oil yields. As it has been proved in previous studies on N. gaditana dry biomass, the combination of different enzymes, such as Viscozyme $^{\circledR}$ (containing a wide range of carbohydrases, including arabinase, cellulase, beta-glucanase, hemicellulase, and xylanase), Celluclast ${ }^{\circledR}$ (containing cellulase), and Alcalase ${ }^{\circledR}$ (a protease cocktail) with other physical methods, enhance and optimize polar lipid recovery. Indeed, N. gaditana cell wall has been reported to be extremely rigid, composed by a structure which difficult the action of the enzymes; thus, it has been demonstrated the need to combine enzymes, both proteases and carbohidrases to successfully break microalgae cell wall, and even this way, the process continues being challenging. The physical methods such as ultrasounds (USs) accelerate the action of the enzymes, showing a synergic effect of both pretreatments, enzymatic and US, on the break of $N$. gaditana cell wall. When each pretreatment was applied separately on the microalgae biomass the oil yield was fewer than the one obtained by their combination, obtaining an effective combined pretreatment previously optimized in other works of the research group (Zuorro et al., 2016; Chen et al., 2017; Zhang et al., 2017; Zhang et al., 2018a; Dixon and Wilken, 2018; Wang et al., 2019; Blanco-Llamero et al., 2021).

The major problem while using soluble enzymes is the production cost, because they are not reusable and are highly unstable under different conditions of microalgae pretreatment, which make it necessary to use high amounts of commercial enzymes. Immobilization is a well-documented alterative for enzyme recycling, improve stability, and reduce the loss of activity under operational conditions of the process. Several approaches for enzyme immobilization can be find in the literature such as adsorption, covalent attachment, entrapment, encapsulation, and cross-linking (Gao et al., 2021); (Chen et al., 2018).

Carrier-free cross-linked enzyme aggregates (CLEAs) are one of the immobilization methods, which has attracted attention due to ease of preparation and robustness of immobilized enzymes without the need of support (Figure 1). CLEAs are prepared in several steps; a first one of enzyme aggregation is produced by mixing them with the precipitant agent (e.g., ammonium sulfate, organic solvents, or polymers) in aqueous solutions, in which enzymatic solutions have to contain a determined protein concentration to produce the aggregates. If the enzymatic solution does not contain enough protein concentration, then protein feeders such as bovine serum albumin (BSA) or other protein can be added to facilitate enzyme precipitation and CLEA handling. The second step during CLEA preparation involves the irreversible insolubilization of the enzyme aggregation by a cross-linking procedure. There are various crosslinking agents described in the literature, among which glutaraldehyde (GA) is the most employed one because of its high reactivity, availability, and low price. When GA is the crosslinker, enzyme aggregates are irreversibly bonded through covalent bonds between its free amino groups (mainly from lysine residues) and both aldehyde moieties of GA, yielding an insoluble biocatalyst with high stability and activity. It must be emphasized the importance of the cross-linking agent because it prevents the leaching of the enzyme and can cause steric hindrance. In this work, the effect of the cross-linker was not studied, and GA was used for CLEA production, as it was previously optimized in other studies. On the contrary, the action of the precipitant agent was deeply studied due to the potential interaction of the different enzymes with them due to their different structures (Velasco-Lozano, 2020; Hero et al., 2020; Xu et al., 2020; Bilal et al., 2021; Guajardo et al., 2021).

On the other hand, the use of combi-CLEAs (coimmobilization of two or more enzymes in a single CLEA for the sole purpose of performing two or more sequential biotransformations) reduces the cost of production at industries and produces better yield as compared to multi-step reactions integrating them into a one-pot process. They also have the benefit of fewer unit operations, less solvent, shorter cycle times, and less waste, resulting in economic and environmental advantages. Furthermore, one-pot reactions can be used to achieve equilibria toward product and biomass, which may be a high advantage in enzymatic procedures. (Perwez et al., 2021).

In the present work, CLEA and combi-CLEA containing Viscozyme ${ }^{\circledR}$, Alcalase $^{\circledR}$, and Celluclast ${ }^{\circledR}$ have been developed and compared with soluble free enzymes regarding thermal and $\mathrm{pH}$ stability, to then be applied in microalgae aqueous pretreatment combined with USs to enhance lipid recovery from biomass.

\section{MATERIAL AND METHODS}

\subsection{Materials}

Nannochloropsis gaditana dry biomass was provided by Cianoalgae SL. (Madrid, Spain). Absolute ethanol (PRS grade), acetone, polyethylene glycol (PEG) 4000, sodium hydrogen 
carbonate, and potassium hydroxide were purchased from Panreac Química S.A (Barcelona, Spain). The water used was Milli-Q grade (Millipore Sigma, Burlington, MA, United States). Viscozyme ${ }^{\circledR}$ from Aspergillus aculeatus containing a wide range of carbohydrases, including arabinase, cellulase, beta-glucanase, hemicellulase, and xylanase; Celluclast ${ }^{\circledR}$ from Trichoderma reesei containing cellulase; and Alcalase ${ }^{\circledR}$ were kindly donated by Novozymes (Bagsvaerd, Denmark). The substrate Boc-AlaOnp (NPA), 3,5-Dinitro-2-hydroxybenzoic acid (DNS), carboxymethylcellulose sodium salt $(\mathrm{CMC})$, potassium sodium tartrate tetrahydrate (Rochelle salts), acetonitrile, and GA solution 25\% were purchased from Sigma (Burlington, MA, United States). All other reagents and solvents used were of analytical or HPLC grade.

\subsection{Bradford Method for Protein Quantification}

The protein concentration was determined by Bradford (Bradford, 1976). The samples were diluted $(1 / 2,1 / 5,1 / 10$, and $1 / 20$ ) to obtain different enzymatic solutions. To perform the measurements, $20 \mu \mathrm{l}$ of the sample was added to $1 \mathrm{ml}$ of Bradford's solution and allowed to react for $30 \mathrm{~min}$. The absorbance was measured at $595 \mathrm{~nm}$ on a model UV-Vis UV1280 spectrophotometer. The absorbance range of the samples must be between 0.1 and 1 for measurements to be reliable. Different concentrations were obtained from a known standard curve for BSA. Protein determinations were performed at least in duplicate in all cases.

\subsection{Spectrophotometric Assays}

\subsubsection{Determination of Alcalase ${ }^{\circledR}$ Activity by NPA Hydrolysis}

The determination of enzyme activity was carried out by using the substrate Boc-Ala-Onp (NPA), according to the methodology presented in other works (Kimberle et al., 2020). The hydrolysis of the substrate (100 mM NPA, prepared in acetonitrile) was conducted at $\mathrm{pH} 7$ (50 mM sodium phosphate buffer, containing $20 \%$ of ethanol) and $25^{\circ} \mathrm{C}$. The product formation was quantified in a spectrophotometer $(405 \mathrm{~nm})$, and the enzyme activity was expressed in UNPA (1UNPA = amount of enzyme that was capable of hydrolyzing $1 \mu \mathrm{mol}$ of substrate per minute at $\mathrm{pH} 7$ and $25^{\circ} \mathrm{C}$ ). The immobilization yield in terms of activity was defined as the expressed activity of the biocatalyst with respect to the initial activity offered. Initial activity of commercial Alcalase ${ }^{\circledR}$ was $2.4 \mathrm{U} / \mathrm{g}$.

\subsubsection{Determination of Celluclast ${ }^{\circledR}$ and Viscozyme ${ }^{\circledR}$ Activity}

Several methods exist for assaying cellulase enzyme activity. Among those, carboxymethyl-Cellulase "CMCase" was used in this research. Celluclast ${ }^{\circledR}$ and Viscozyme ${ }^{\circledR}$ activity was measured by dinitrosalicylic acid method (DNS), using glucose as a standard and measuring its absorbance by UV-Vis spectroscopy at $540 \mathrm{~nm}$ (Romero-Fernández et al., 2018). For DNS preparation, $200 \mathrm{ml}$ of water under stirring was heated until $100^{\circ} \mathrm{C}$; once the temperature was achieved, $10 \mathrm{~g}$ of DNS were added slowly. Once the mixture became homogeneous, $16 \mathrm{~g}$ of $\mathrm{NaOH}$ were added, and finally, $300 \mathrm{~g}$ of Rochelle salts. The mixture was made up to $1 \mathrm{~L}$ with water.

The activity assay was performed as follows: $0.8 \mathrm{ml}$ of substrate (CMC) was mixed with $0.2 \mathrm{ml}$ of commercial enzyme, and they were incubated for $10 \mathrm{~min}$. After this time, $1 \mathrm{ml}$ of the prepared DNS was added, boiled for $5 \mathrm{~min}$, and cool down in iced water. Water $(9 \mathrm{ml})$ was added to each sample, and the absorbance was measured at $540 \mathrm{~nm}$ to study the glucose concentration that was liberated. One unit of enzyme activity was defined as the amount of enzyme required to release $1 \mu \mathrm{mol}$ of reducing sugars in $1 \mathrm{~min}$ (Zuorro et al., 2016; Chen et al., 2018; Poorakbar et al., 2018). The activity of commercial Viscozyme ${ }^{\circledR}$ and Celluclast ${ }^{\circledR}$ was 100 and $700 \mathrm{U} / \mathrm{g}$, respectively.

\subsection{CLEAs and Combi-CLEAs Formation 2.4.1 Protein Concentration}

For CLEA production, it is recommendable to work with protein concentrations between 2 and $100 \mathrm{mg} / \mathrm{ml}$. In this work, after protein quantification of commercial enzymes by Bradford, CLEAs and combi-CLEAs were performed in all cases using a final concentration of $20 \mathrm{mg} / \mathrm{ml}$. For single CLEAs, $20 \mathrm{mg} / \mathrm{ml}$ of each enzyme was prepared in separated carrier-free derivatives. In the case of combi-CLEAs, a mixture containing Viscozyme ${ }^{\circledR}$, Celluclast ${ }^{\circledR}$, and Alcalase ${ }^{\circledR}$ (one third of each commercial enzyme to a final concentration of $20 \mathrm{mg} / \mathrm{ml}$ ) was used.

\subsubsection{Screening of Different Precipitants in the First Step of Single CLEA Formation}

In the present work, three different precipitants were studied to test the distinct interaction between precipitants and enzymes to develop the first step in CLEA formation. Two organic solvents (ethanol and acetone) and one polymer (PEG 4000) were studied at different ratios $(60 \%-90 \%$ and $50 \%-90 \%$, respectively). The three precipitants were all studied in combination with the three commercial enzymes (Viscozyme ${ }^{\circledR}$, Celluclast ${ }^{\circledR}$, and Alcalase ${ }^{\circledR}$ ), developing single CLEAs of each enzyme separately.

The first step in CLEA formation (precipitation) was developed as follows: $20 \mathrm{mg} / \mathrm{ml}$ of enzymatic solution (the corresponding volume was determined for each commercial enzyme taking into account the protein concentration) was mixed with precipitant agent (prepared at different ratios in distilled water) in a final volume of $4 \mathrm{ml}$. The mixture was gently mixed at room temperature during $15 \mathrm{~min}$ until the solution appeared visibly turbid.

\subsubsection{Cross-Linking With Glutaraldehyde in the Second Step of Single CLEA Formation}

In this step, GA was immediately added to the solutions to obtain a defined concentration of $75 \mathrm{mM}(20 \mu \mathrm{l}$ of GA solution $25 \%)$ and vigorously mixed by vortexing for $1 \mathrm{~min}$. The mixtures were then incubated during $20 \mathrm{~h}$ at $4^{\circ} \mathrm{C}$ under vigorous agitation. After cross-linking time, the preparations were centrifuged at 5,000 g for $30 \mathrm{~min}$ at $4^{\circ} \mathrm{C}$, and the supernatant was discarded (containing enzymes that did not react). To resuspend and wash the CLEAs, $5 \mathrm{ml}$ of buffer solution was added and mixed by vortexing for $5 \mathrm{~min}$ and centrifuged again. The wash step was repeated three 
times to remove traces of reagent. Finally, the CLEAs were resuspended in the buffer solution at a proper concentration to assay their enzymatic activity spectrophotometrically and their protein concentration by Bradford to calculate the immobilization yield and compare them (Velasco-Lozano, 2020; Zhang et al., 2018b). The immobilization yield of CLEAs was calculated by the ratio of enzyme units (calculated by the protein in the supernatant) to the total unit of enzymes loaded for immobilization.

\subsubsection{Combi-CLEA Formation Under Optimal Conditions}

Once the optimized conditions for CLEA formation for different enzymes assayed were obtained using different precipitants (acetone, ethanol, and PEG), they were used to obtain combiCLEAs. The protocol was the same as for the separated CLEAs. Briefly, the enzymatic mixture containing the three enzymes at final concentration of $20 \mathrm{mg} / \mathrm{ml}$ was mixed with precipitants in separated experiments (acetone at $90 \%$, ethanol at $90 \%$, and PEG at $80 \%$ ) and incubated at room temperature under stirring for $15 \mathrm{~min}$. Then, GA was added and incubated overnight at $4^{\circ} \mathrm{C}$ under vigorous stirring. After that, mixtures were centrifuged, and combi-CLEAs were obtained in the pellet (supernatant was discarded). Combi-CLEAs were washed three times to remove traces of reagents. Immobilization yield was obtained in the same was as for the separated CLEAs.

\subsection{Inactivation Assays of Carrier-Free Biocatalysts}

The determination of biocatalysts stability was carried out at different temperatures $\left(50^{\circ} \mathrm{C}\right.$ and $\left.55^{\circ} \mathrm{C}\right)$ and different $\mathrm{pH}(25 \mathrm{mM}$ phosphate buffer at $\mathrm{pH} 7$ and acetate buffer at $\mathrm{pH}$ 5.0), containing the same amount of protein to compare the results. Aliquots were withdrawn for $24 \mathrm{~h}$. Each sample was analyzed at different times by measuring its enzymatic activity as described above. Residual activity was calculated as the ratio between activity at a given time and the activity at the beginning of incubation. Half-life times (time in which the residual enzyme activity is half of its initial value) were calculated as previously described in the literature (Romero et al., 2012). Stabilization factors were determined by comparing half-life times of different derivatives and a reference.

\subsection{Enzymatic Pretreatment of Microalgae Using CLEAs and Combi-CLEAs}

The optimum CLEAs and combi-CLEAs obtained were applied to microalgae using the pretreatment described below and compared to soluble enzymes in terms of oil yield extracted [using the Folch method (Folch et al., 1957)] and microalgal cell wall disruption rate studied by scanning electron microscopy (SEM).

The protocol of the optimized enzymatic pretreatment of $N$. gaditana biomass was previously described in literature (BlancoLlamero et al., 2021). One gram of dry microalgal biomass was resuspended in $10 \mathrm{ml}$ of sodium citrate buffer $0.1 \mathrm{M} \mathrm{pH} 5.0$ containing soluble enzymes $(20 \mathrm{mg} / \mathrm{ml}$ containing the three soluble commercial enzymes), single CLEAs (containing $20 \mathrm{mg} / \mathrm{ml}$ of each enzyme in the separated CLEAs), or combiCLEAs (combined CLEAs containing a mixture of the three commercial enzymes at a final concentration of $20 \mathrm{mg} / \mathrm{ml}$ ) per gram of biomass. In addition, $1 \mathrm{~g}$ of biomass was resuspended in a $10 \mathrm{ml}$ buffer of without enzymes (blank solution). US-assisted enzymatic pretreatment was carried out with a US bath Elmasonic S40H Elma brand (Singen, Germany) with automatic control of time $(6 \mathrm{~h})$ and temperature $\left(55^{\circ} \mathrm{C}\right)$, US frequency of $37 \mathrm{kHz}$, and bath power of $140 \mathrm{~W}$.

The flask content was centrifuged at 3,000 rpm for $10 \mathrm{~min}$, the supernatant was discarded, and pellet biomass was kept at $4^{\circ} \mathrm{C}$ for its extraction by the Folch method and characterization. Experiments were performed at least in triplicate in all cases.

\subsection{SEM-EDX Analyses of CLEAs}

To envisage surface morphologies, images of CLEAs were captured using SEM (Hitachi, TM-1000). For observing CLEA particles under SEM energy-dispersive X-ray (SEM-EDX) analytical system, a droplet of CLEA sample was dispensed on a polycarbonate track-etched membrane, freeze-dried, and platinum-coated using a sputtering coater. Structural characterization of CLEAs and pretreated microalgae biomass were analyzed.

\subsection{Statistical Analysis}

The results were expressed as the mean of the experiments and its SD.

Statistical analysis was performed in the SISA (Simple Interactive Statistical Analysis) online software available at http://www.quantitativeskills.com/sisa/statistics/ttest.htm

(accessed August 20, 2021). The data were subjected to a t-test to examine whether the two groups mean differ from one another. To test whether there is an overall statistically significant difference between three or more means, the data were subjected to a one-way analysis of variance using the F-test for discrimination between means $(p<0.05)$.

\section{RESULTS AND DISCUSSION}

\subsection{Development of Alcalase ${ }^{\circledR}$-CLEAs 3.1.1 Screening of Different Precipitants for CLEA Production}

The first step during CLEA preparation consists in the formation of active enzyme aggregates. To this aim, a preliminary screening of non-denaturant precipitants was conducted by testing the precipitant efficiency and the residual activity of the precipitated enzyme expressed in Table 1.

Thus, in a first set of experiments, the cross-linking immobilization of Alcalase ${ }^{\circledR}$ was explored. Several parameters need to be considered, such as the selection of the precipitating agent, the ratio of the precipitant, and the need or not of adding BSA to achieve a biocatalyst with good physical characteristics (to be recovered after centrifugation) with high activity and high immobilization performance. The effect of precipitant type and ratio on activity recovery and formation of CLEAs was evaluated. 
TABLE 1 | Immobilization performance of Alcalase ${ }^{\circledR}$-CLEAs at different precipitant conditions.

\begin{tabular}{|c|c|c|c|c|}
\hline Precipitant type & Precipitant concentration (\%) & Immobilization yield (\%) & Immobilized protein (mg) & $\begin{array}{c}\text { Enzymatic activity of } \\
\text { immobilized Alcalase (U/g) }\end{array}$ \\
\hline \multirow[t]{4}{*}{ Ethanol } & 60 & $76.67 \pm 0.26$ & $15.33 \pm 0.30$ & $1.33 \pm 0.21$ \\
\hline & 70 & $82.87 \pm 0.31$ & $16.57 \pm 0.39$ & $1.39 \pm 0.11$ \\
\hline & 80 & $90.38 \pm 0.40$ & $18.08 \pm 0.27$ & $1.81 \pm 0.32$ \\
\hline & 90 & $96.65 \pm 0.16$ & $19.33 \pm 0.81$ & $2.22 \pm 0.24$ \\
\hline \multirow[t]{4}{*}{ Acetone } & 60 & $93.47 \pm 0.18$ & $18.69 \pm 0.13$ & $1.97 \pm 0.30$ \\
\hline & 70 & $94.73 \pm 0.22$ & $18.95 \pm 0.52$ & $2.32 \pm 0.17$ \\
\hline & 80 & $98.71 \pm 0.61$ & $19.74 \pm 0.14$ & $2.14 \pm 0.22$ \\
\hline & 90 & $98.28 \pm 0.66$ & $19.66 \pm 0.26$ & $2.26 \pm 0.10$ \\
\hline \multirow[t]{5}{*}{ PEG } & 50 & $92.45 \pm 0.56$ & $18.49 \pm 0.32$ & $2.26 \pm 0.31$ \\
\hline & 60 & $87.82 \pm 0.39$ & $17.56 \pm 0.61$ & $2.33 \pm 0.08$ \\
\hline & 70 & $86.40 \pm 0.20$ & $17.28 \pm 0.25$ & $1.93 \pm 0.19$ \\
\hline & 80 & $87.82 \pm 0.78$ & $17.56 \pm 0.42$ & $1.94 \pm 0.09$ \\
\hline & 90 & $83.19 \pm 0.85$ & $16.64 \pm 0.36$ & $1.75 \pm 0.23$ \\
\hline
\end{tabular}

Acetone and ethanol (organic solvents) and PEG 4000 and PEG at different concentrations $(60 \%-90 \%$ and $50 \%-90 \%$, respectively) (non-ionic polymers) were studied at $20^{\circ} \mathrm{C}$ and using GA as cross-linking agent. The immobilization yield was tested in terms of protein concentration determined by Bradford and in terms of enzyme activity with spectrophotometric activity assay to corroborate the results. Results are detailed in Table $\mathbf{1}$ and expressed as the average between both immobilization yields.

The best percentage of immobilized Alcalase ${ }^{\circledR}$ was achieved in the case of acetone, which ranged from $93 \%$ to $98 \%$ for all the ratios tested, followed by ethanol, which varied from $76 \%$ to $96 \%$. In general, the immobilization yield increased when the concentration of the organic precipitant grew. On the other hand, taking PEG as a precipitant agent, it appeared to follow the opposite trend than ethanol and acetone, and the immobilized percentage increased as the PEG concentration decreased, either taking into account protein concentration or enzyme activity. This result is in agreement with previous works where amounts around $50 \%$ of PEG were shown to produce huge and stable molecular aggregates, whereas higher percentages provoke distortions in the enzyme structure leading to non-stable aggregates (García-García et al., 2021). Interestingly, PEG at $50 \%$ of concentration resulted in slightly higher results than the $60 \%$ conditions. Thus, both conditions were selected to be further investigated in the stability test.

In summary, combining both analyses (immobilization yield and recovered activity), the best precipitant agents were ethanol at $90 \%$, acetone at $90 \%$ and $70 \%$, and PEG at $50 \%$ and $60 \%$. Ethanol at $90 \%$ was selected due to its higher activity and immobilization yield, compared to the other precipitant conditions. Although acetone at $90 \%$ led to higher immobilization rate, its enzymatic activity resulted to be lower, so acetone at $70 \%$ was also selected. Moreover, PEG at $50 \%$ and $60 \%$ was also chosen. These conditions were selected to be tested in the inactivation assays, and this way selects the final conditions.

\subsubsection{Kinetic Characterization of Free Alcalase ${ }^{\circledR}$ and Alcalase ${ }^{\circledR}$-CLEAs by Inactivation Assays}

To further compare between different immobilization conditions (ethanol at $90 \%$, acetone $90 \%$ and $70 \%$, and PEG 50\% and 60\%), stability assays were performed in different temperature and $\mathrm{pH}$ conditions comparing free enzymes and CLEAs. The conditions were chosen in regard to the optimum conditions of previous works on N. gaditana pretreatment using the combination of the three enzymes (Mahdy et al., 2014; Safi et al., 2017; BlancoLlamero et al., 2021), using this model as a proof of concept of the derivatives activity on microalgae and taking it as the final objective of the present study.

It is interesting to point out that CLEAs produced were more stable than the soluble enzymes because the derivatives facilitate the stabilization of the enzyme by creating a strong bonding between the amino groups of the enzyme molecule and GA. Furthermore, the structural organization of CLEAs drastically avoids conformational modifications, resulting in higher $\mathrm{pH}$ tolerance than free enzymes. Stability assays at $55^{\circ} \mathrm{C}$ and $\mathrm{pH}$ 5.0 (Figure 2) revealed that free soluble enzyme half-life was achieved before $30 \mathrm{~min}$ of assay. On the other hand, CLEAs tested maintained the total activity for $15 \mathrm{~min}$, and then, it started to decrease dramatically. This fact could be attributed to the aggressive conditions tested because at medium-high temperature, each degree could be critical for the integrity of the enzyme; thus, lower temperature $\left(50^{\circ} \mathrm{C}\right)$ was tested at $\mathrm{pH} 5.0$.

Considering $50^{\circ} \mathrm{C}$ and $\mathrm{pH} 5.0$ (Figure 3), all the CLEAs and the soluble Alcalase ${ }^{\circledR}$ increased their stability compared to $55^{\circ} \mathrm{C}$, as expected. There were clear differences between acetone at $70 \%$ and $90 \%$, which were similar in terms of immobilization percentage. Acetone at $70 \%$ lost $50 \%$ of its initial activity at $30 \mathrm{~min}$, whereas acetone at $90 \%$ achieve this level at $2 \mathrm{~h}$. Nevertheless, both of them only retains $20 \%$ of its initial activity at $4 \mathrm{~h}$. In addition, it could be seen big differences between PEG at different rates, showing better stability $60 \%$ compared to 50\% (Sheldon, 2006; Bilal et al., 2021).

On the other hand, ethanol at $90 \%$ resulted to be the biocatalyst with the best stability, maintaining $50 \%$ of activity at $4 \mathrm{~h}$, whereas the other CLEAs only retained $20 \%$ of its initial activity at this stage. As it can be seen in Figure 3, the kinetic of inactivation of the CLEA was less dramatic with ethanol at $90 \%$ than compared to the other conditions. With regard to the soluble enzyme, its kinetic of inactivation was very rapid, with a half-life time of less than $30 \mathrm{~min}$. This result compared to that obtained for CLEAs in ethanol at $90 \%$ results in a derivative 10 times more stable than the soluble enzyme. 


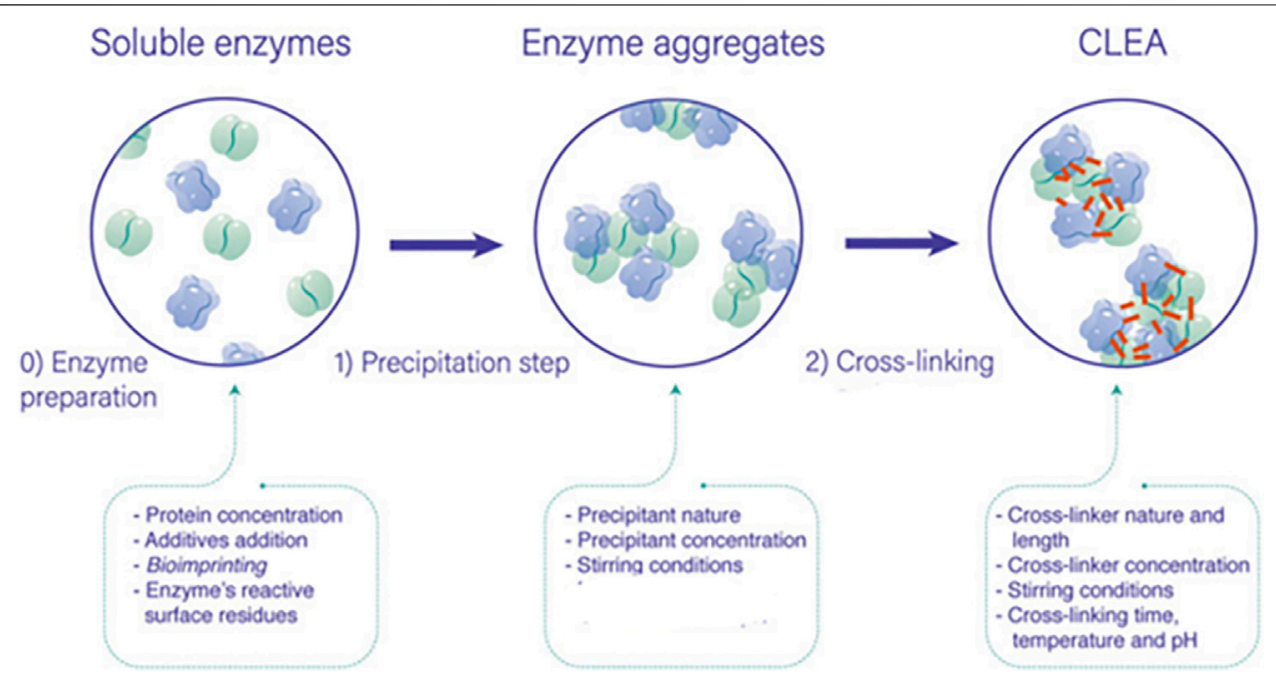

FIGURE 1 | General process for the preparation of cross-linked enzyme aggregates (CLEAs) and the possible variables governing its final performance (VelascoLozano, 2020).

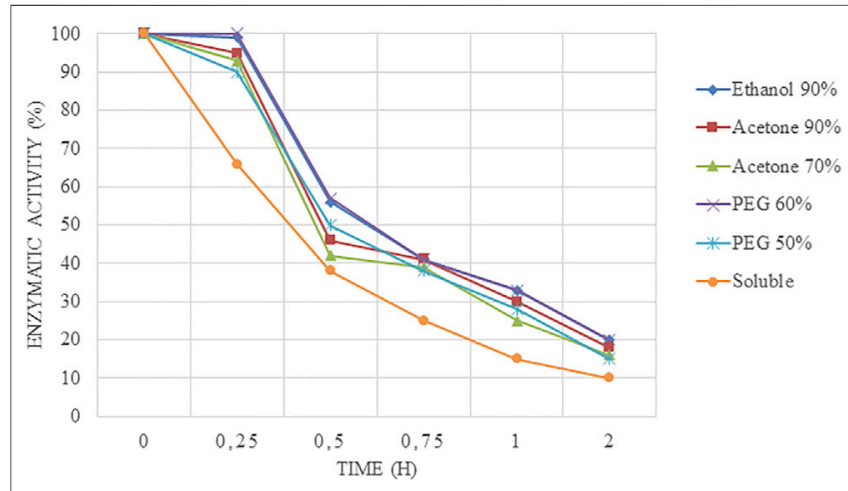

FIGURE 2 | Time course of inactivation at $55^{\circ} \mathrm{C}$ and $\mathrm{pH} 5.0$ at different times of Alcalase ${ }^{\circledR}$-CLEAs using PEG, ethanol, and acetone as precipitants.

When carrier-free derivatives were tested at $\mathrm{pH} 7.0$ and $50^{\circ} \mathrm{C}$ to test a neutral $\mathrm{pH}$ as well (Figure 4), no differences were found between the different immobilized biocatalysts (acetoneAlcalase ${ }^{\circledR}$-CLEAs, PEG-Alcalase ${ }^{\circledR} \quad$ CLEAs, and ethanolAlcalase ${ }^{\circledR}$-CLEAs) because they retained over $80 \%$ of their relative activities without differences between them. However, the free enzyme lost $50 \%$ of its relative activity at $2 \mathrm{~h}$.

Thus, immobilization of Alcalase ${ }^{\circledR}$ in CLEAs results in a remarkably improvement in temperature resistance due to biocatalyst rigidity attributed to the stabilization of threedimensional structure of the protein, which contributes to higher activity than the free enzymes due to conformational changes in enzymes structure.

\subsection{Development of Celluclast ${ }^{\circledR}$-CLEAs}

The results obtained from the Celluclast ${ }^{\circledR}$-CLEA production (Table 2) in terms of protein concentration and enzymatic activity of the derivative mostly coincided with the ones resulted

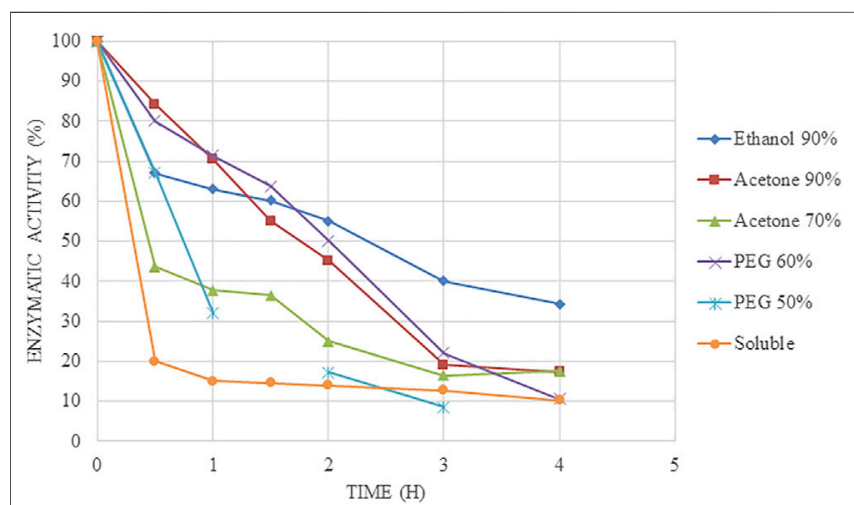

FIGURE 3 | Time course of inactivation at $50^{\circ} \mathrm{C}$ and $\mathrm{pH} 5.0$ at different times of Alcalase ${ }^{\circledR}$-CLEAs using PEG, ethanol, and acetone as precipitants.

from the Alcalase ${ }^{\circledR}$-CLEAs, because the best conditions for acetone and ethanol were both $90 \%$ ratio with a remarkably high protein loaded in both cases (99\%). However, the results also had some differences from the previous ones, because CLEAs were not formed at all of the conditions tested. In fact, ethanol at lower ratios was not able to produce visible CLEAs, so occurs with acetone at the lowest ratio tested $(60 \%)$. These differences could be attributed to the different enzymatic structure of Alcalase $^{\circledR}$ and Celluclast ${ }^{\circledR}$, producing different interaction with the precipitant agents. This fact highlights the importance to optimize immobilization conditions for each enzyme separately. On the other hand, all of the ratios tested for PEG as a precipitant agent obtained similar immobilization results.

It is interesting to highlight the higher immobilization recovery obtained in this work compared with previous works on CLEAs with other enzymes, in which the best immobilization rate did not go up from $30 \%$ to $70 \%$ for PEG, ammonium sulfate, n-propanol, acetone, 


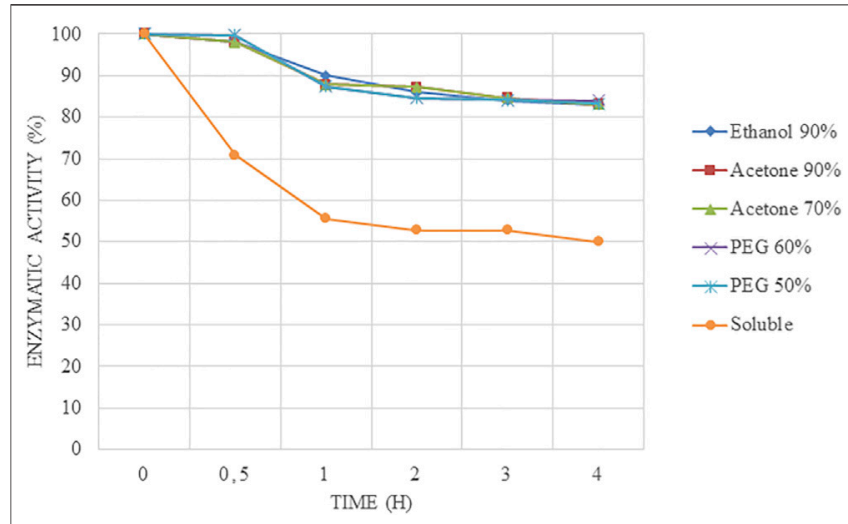

FIGURE 4 | Stability results at $50^{\circ} \mathrm{C}$ and $\mathrm{pH} 7.0$ at short times of Alcalase ${ }^{\circledR}$-CLEAs using PEG, ethanol, and acetone as precipitants.

and tert-butanol as precipitant agents, whereas in the present study, the results up to $80 \%$ were obtained for all the enzymes studied (Bilal et al., 2021; Xu et al., 2020; Perwez et al., 2021).

Immobilization rates were also studied in terms of enzymatic activity for Celluclast ${ }^{\circledR}$ and Viscozyme ${ }^{\circledR}$ (data not shown), which coincided with the results obtained in terms of protein concentration shown in Table 2.

\subsection{Development of Viscozyme ${ }^{\circledR}$-CLEAs}

Viscozyme ${ }^{\circledR}$-CLEAs results were the ones that differed the most from the other ones (Table 3), which may be due to the fact that Viscozyme ${ }^{\circledR}$ is already an enzymatic cocktail containing different enzymes and generating different interactions with the materials tested. Indeed, these CLEAs could be considered already combi-CLEAs because different enzymes were immobilized successfully obtaining visible CLEAs. Analyzing results deeper, the immobilized percentage for all the conditions was slightly lower than the one obtained with the previous enzymes, which could be explained because it is more difficult to immobilize more enzymes compared to one due to the complex interaction that could appear between all of them. Although, the percentages achieved could be considered as high ones compared to previous works on CLEAs with other enzymes (Bilal et al., 2021; Xu et al., 2020; Perwez et al., 2021).
The best immobilization conditions for Viscozyme ${ }^{\circledR}$ resulted to be acetone at $80 \%$ and $90 \%$ and ethanol at $90 \%$ as occurred with the other enzymes and PEG at all the ratios tested.

\subsection{Development of Combi-CLEAs Under Optimized Process Parameters}

Combi-CLEAs were produced mixing the three enzymes at a proper concentration (final concentration of $20 \mathrm{mg} / \mathrm{ml}$ ) before adding the precipitant agent and following the same method as the one used for CLEAs of each enzyme. On the basis of the obtained results, combi-CLEAs including Alcalase ${ }^{\circledR}$, Celluclast $^{\circledR}$, and Viscozyme ${ }^{\circledR}$ were intended, employing the best conditions for the three enzymes and using compromise conditions when it was needed. The chosen conditions resulted to be acetone at $90 \%$, ethanol at $90 \%$, and PEG at $80 \%$. Combi-CLEAs were produced successfully with interesting immobilization rates (over 90\%). Immobilization performance was similar for the three derivatives (Figure 5).

Stability of the best combi-CLEAs obtained was also investigated employing the stability conditions that resulted more illustrated previously $\left(50^{\circ} \mathrm{C}\right.$ and $\left.\mathrm{pH} 5.0\right)$ (data not shown). It is interesting to highlight the fact that the combiCLEAs was less stable than the CLEAs of each enzyme separately, as it was expected because of the complexity of the derivatives. Even so, the combi-CLEAs were remarkably more resistant than the soluble derivatives at the same conditions, so they were also selected for microalgae pretreatment.

\subsection{Application of CLEAs and Combi-CLEAs on Microalgae Pretreatment to Break Cell Wall}

As a proof of concept, on the basis of the previous works on USassisted microalgae pretreatment and extraction (Bautista et al., 2015; Sánchez-Bayo et al., 2019; Sheldon, 2019; Blanco-Llamero et al., 2021), enzymatic reactions were carried out with optimum CLEAs and combi-CLEAs (using ethanol at $90 \%$, acetone at $90 \%$, and PEG at $80 \%$ ) combined with US and compared to soluble Alcalase ${ }^{\circledR}$, Viscozyme $^{\circledR}$, and Celluclast ${ }^{\circledR}$ also combined with US. All preparations could be compared in terms of oil yield because they had the same amount of enzyme. A blank test without

TABLE 2 | Immobilization performance of Celluclast ${ }^{\circledR}$-CLEAs at different precipitant conditions.

\begin{tabular}{|c|c|c|c|c|}
\hline Precipitant type & Precipitant concentration (\%) & Immobilization yield (\%) & Immobilized protein (mg) & $\begin{array}{c}\text { Enzymatic activity of } \\
\text { immobilized Celluclast }(\mathrm{U} / \mathrm{g})\end{array}$ \\
\hline Ethanol & 90 & $99.20 \pm 0.12$ & $19.84 \pm 0.10$ & $679.26 \pm 0.85$ \\
\hline \multirow[t]{3}{*}{ Acetone } & 70 & $98.25 \pm 0.14$ & $19.65 \pm 0.11$ & $561.73 \pm 0.47$ \\
\hline & 80 & $98.70 \pm 0.06$ & $19.74 \pm 0.10$ & $648.15 \pm 0.55$ \\
\hline & 90 & $99.38 \pm 0.48$ & $19.87 \pm 0.31$ & $677.53 \pm 0.48$ \\
\hline \multirow[t]{5}{*}{ PEG } & 50 & $95.05 \pm 0.37$ & $19.01 \pm 0.20$ & $566.91 \pm 1.21$ \\
\hline & 60 & $96.36 \pm 0.18$ & $19.27 \pm 0.15$ & $509.88 \pm 1.03$ \\
\hline & 70 & $97.67 \pm 0.62$ & $19.53 \pm 0.31$ & $573.83 \pm 0.95$ \\
\hline & 80 & $98.64 \pm 0.34$ & $19.72 \pm 0.26$ & $658.52 \pm 0.86$ \\
\hline & 90 & $95.87 \pm 0.52$ & $19.17 \pm 0.38$ & $623.26 \pm 0.77$ \\
\hline
\end{tabular}


TABLE 3 | Immobilization performance of Viscozyme ${ }^{\circledR}$-CLEAs at different precipitant conditions.

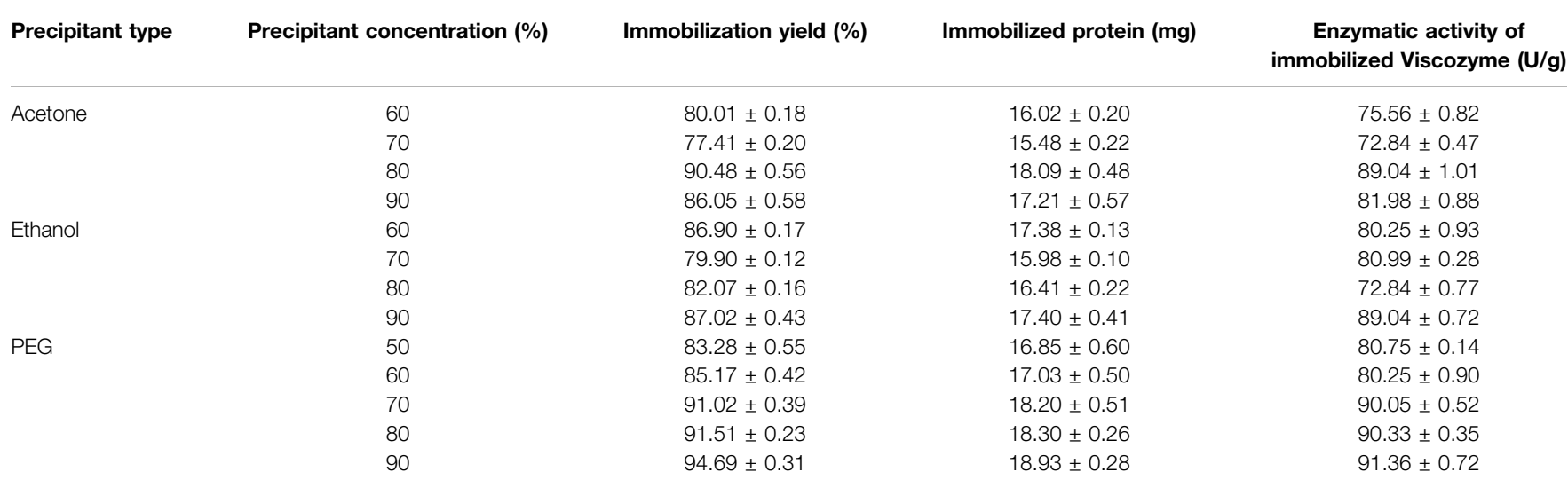

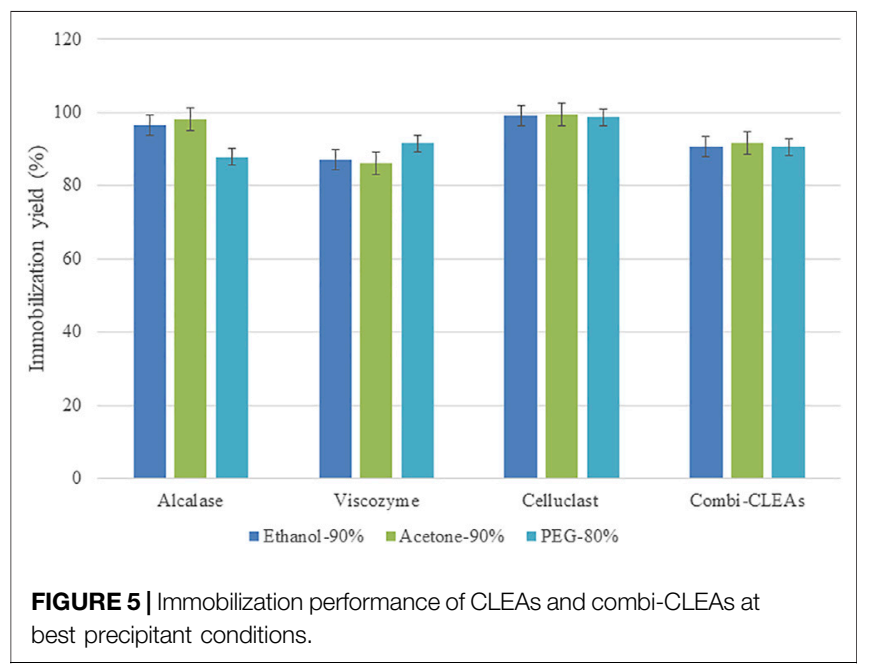

biocatalyst was conducted to observe US effects on N. gaditana cell wall. Results were also compared with untreated microalgal oil recovery.

In Figure 6, it should be pointed out that the oil yield of the microalgae extraction slightly increased when the US bath was used on its own (14.56\%) compared with the initial time (12.02\%). However, remarkably, higher results were obtained when enzymes in combination were added to the process (23.65\%), doubling the results obtained by initial time $(p<$ $0.05)$, demonstrating the effect of the enzymes in the cell wall breakage and suggesting the potential of this combined pretreatment process.

Oil yields obtained for CLEAs ranged from $27.15 \%$ to $33.23 \%$, whereas the results obtained when the combiCLEAs were employed varied from $29.02 \%$ to $34.11 \%$. Interestingly, when the derivatives were applied to the pretreatment process, the immobilized enzymes, either employing CLEAs or combi-CLEAs, maintained the promising results obtained by the soluble enzymes and they even improved, which may be due to the remarkably higher stability of the derivatives described before. Indeed, the interaction between enzymes and substrate related to combi-CLEAs and microalgae was satisfactory as the derivatives were in the form of aggregates and the microalgae solution was able to enter and interact with the enzymes avoiding mass transfer problems. On the other hand, regarding to the combi-CLEAs, even the difficulties of their production due to the different interactions of the structures of the enzyme in the aggregate, they were obtained satisfactory in the present work, and it is important to highlight the effect of the combi-CLEAs on the microalgae pretreatment. The improvement compared to the soluble enzymes and the CLEAs of each enzyme separated is that this process can obtain all the reactions in one pot within the same aggregate. As it can be seen in Figure 6, the best biocatalyst in terms of oil yield obtained was the one produced under the conditions of ethanol at $90 \%$, either combi-CLEA or CLEA. Indeed, the similarity between the results of CLEAs and combi-CLEAs showed the ability of the biocatalytic process, allowing the transference between the microalgae and the aggregate, suggesting that the enzymes are accessible enough when the three enzymes were combined in one combi-CLEA. This fact supports the production of combi-CLEA, because they maintained the same results and reduce the operational steps, cost, and time of production process.

As a perspective of future, once the effectiveness of combiCLEAs was proved, especially the ones of ethanol at $90 \%$, it will be interesting to produce magnetic combi-CLEAs that make it possible to recover the biocatalyst and recycle it in different cycles of microalgae pretreatment, making the process even more efficient in terms of energy, time, material and economics.

\subsection{Structural Analysis by Scanning Electron Microscopy}

To study morphologic details of the surface of the derivatives, SEM was employed to study the best combi-CLEAs obtained and the microalgae cell wall to study disruption rate and confirm the effectiveness of the method developed. Combi-CLEAs using PEG at $80 \%$ and ethanol and acetone at $90 \%$ were studied (Figure 7 ) and 


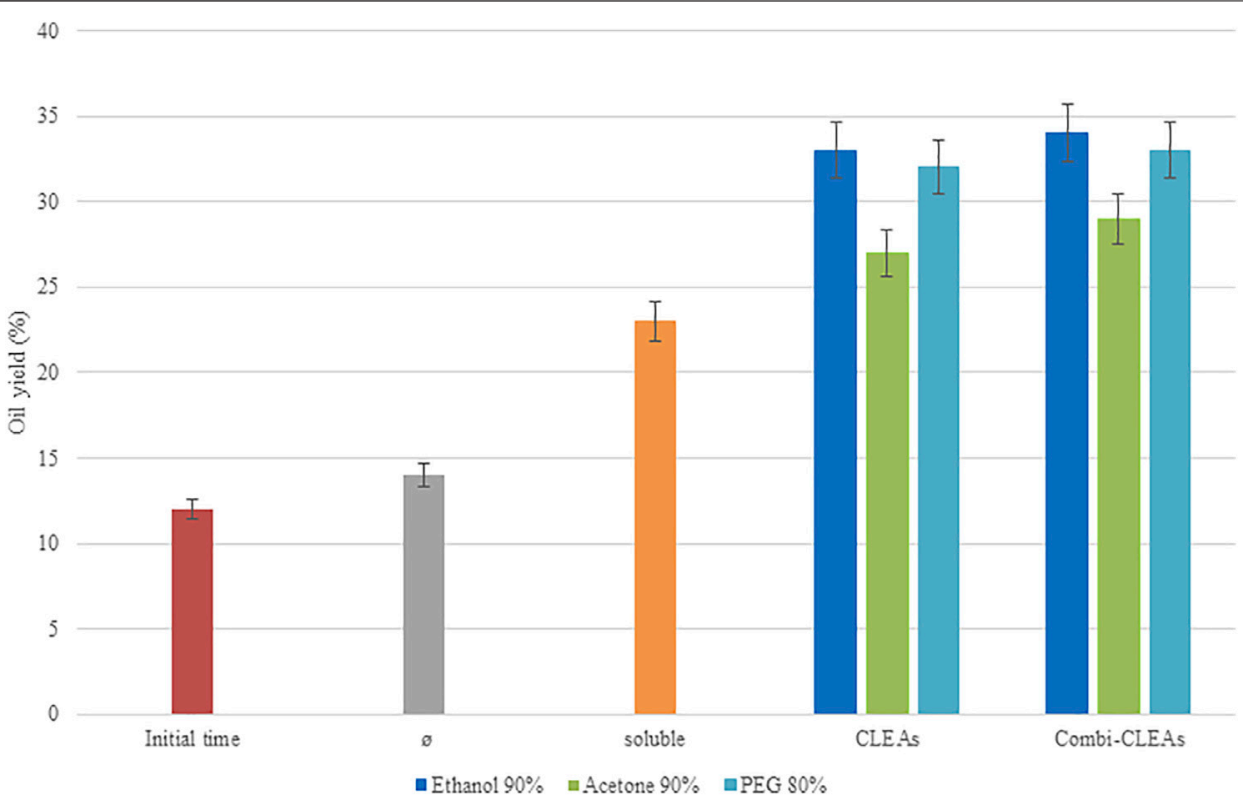

FIGURE 6 | Oil yields (\%) obtained after enzymatic pretreatment of $N$. gaditana biomass at $55^{\circ} \mathrm{C}$ and pH 5.0 during $6 \mathrm{~h}$ in an US bath using soluble enzymes, optimal CLEAs, or optimal combi-CLEAs. Results were compared to initial time (unpretreated biomass) and microalgae biomass incubated in the US bath without enzymes ( $\varnothing$ ).
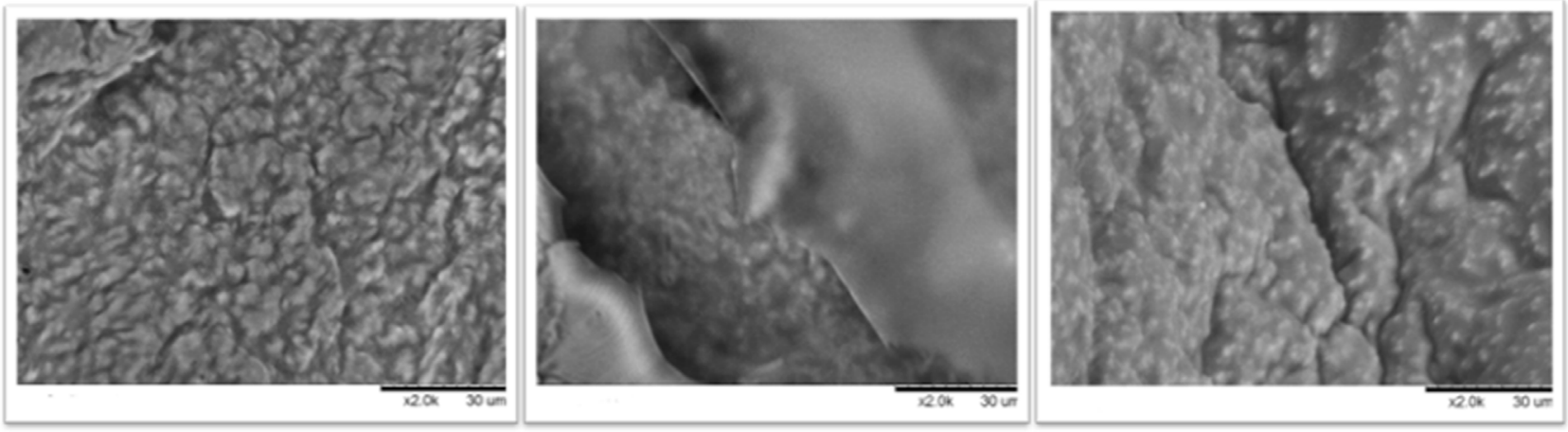

FIGURE 7 | Combi-CLEAs studied by SEM: ethanol at $90 \%$ in the left, acetone at $90 \%$ in the middle, and PEG at $80 \%$ in the right.

compared to the method using soluble enzymes and with the initial time of the intact biomass (Figure 8).

As it can be seen in Figure 7, microalgae cell wall appeared to be broken in great degree using all the combi-CLEAs for the enzymatic pretreatment of Nannochloropsis gaditana cell wall. Furthermore, compared with the initial time, the structure of the biomass was clearly damaged. In both cases, employing either soluble enzymes or carrier-free derivatives, the microalgal cell wall was ruined. These results confirmed the effectiveness of the CLEAs, breaking the microalgal cell wall and their action on microalgae, which is in agreement with the oil yield results obtained from the reactions previously described. Remarkably, microalgae could easily penetrate inside the CLEAs because it was prepared in the form of carrier-free derivatives, avoiding mass transfer difficulties that could happen using traditional derivatives immobilized inside the porous structure of traditional activated supports.

\section{CONCLUSION}

In this work, CLEAs and combi-CLEAs of Alcalase ${ }^{\circledR}$, Viscozyme $^{\circledR}$, and Celluclast ${ }^{\circledR}$ from commercial enzymes solutions for biomass pretreatment are produced and characterized. As relevant results, CLEAs of the three enzymes were successfully produced with high immobilization rates (over $80 \%$ ). Interesting immobilization results were in agreement with the stability test results that were obtained by incubating the derivatives at different conditions and by the results of the proof-of-concept reactions on microalgal biomass. On the other hand, the best-obtained conditions showed its usefulness in the pretreatment of microalgae, facilitating the cell disruption and reducing possible variations due to the instability of soluble enzymes, as it is shown in the increased extraction yield and in the structural morphology of the cell wall by SEM.

As a conclusion, the results obtained show the application of CLEAs as a promising technology for microalgae pretreatment to 

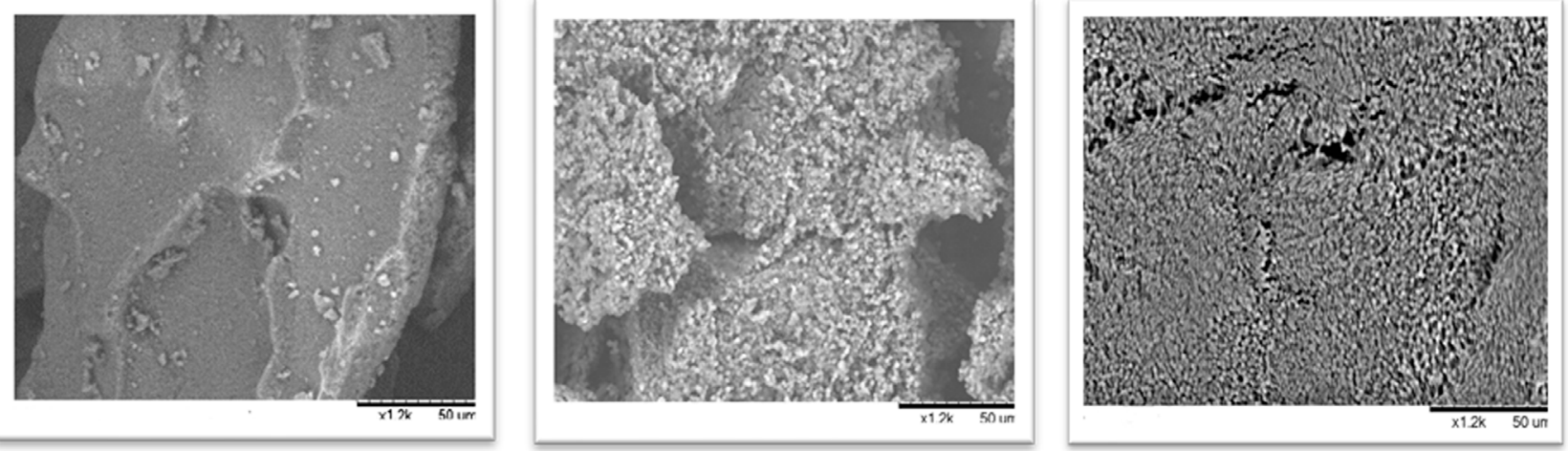

FIGURE 8 |N. gaditana biomass studied by SEM: initial time, up and left; pretreated biomass using soluble enzymes, up and right; and pretreated biomass using CLEAs ethanol at $90 \%$, down.

improve the stability of enzymes commonly used in this biomass and reduce the amount of solvents and energy employed in the subsequent extraction, increasing extraction yield and reducing environmental pollution and global cost of the process (Sheldon, 2019).

\section{DATA AVAILABILITY STATEMENT}

The original contributions presented in the study are included in the article/supplementary material; further inquiries can be directed to the corresponding authors.

\section{AUTHOR CONTRIBUTIONS}

Conceptualization: CB-L, PG-G, and FS. Methodology: CB-L and PGG. Investigation: CB-L, PG-G, and FS. Resources: FS. Writing - original draft preparation: CB-L and PG-G. Writing — review and editing: CBL, PG-G, and FS. Supervision: PG-G and FS. Project administration: FS.

\section{REFERENCES}

Bautista, L. F., Vicente, G., Mendoza, Á., González, S., and Morales, V. (2015). Enzymatic Production of Biodiesel From Nannochloropsis Gaditana Microalgae Using Immobilized Lipases in Mesoporous Materials. Energy Fuels. 29, 4981-4989. doi:10.1021/ef502838h

Bilal, M., Noreen, S., Asgher, M., and Parveen, S. (2021). Development and Characterization of Cross-Linked Laccase Aggregates (Lac-CLEAs) From Trametes versicolor IBL-04 as Ecofriendly Biocatalyst for Degradation of Dye-Based Environmental Pollutants. Environ. Technology Innovation. 21, 101364. doi:10.1016/j.eti.2021.101364

Blanco-Llamero, C., García-García, P., and Señoráns, F. J. (2021). Combination of Synergic Enzymes and Ultrasounds as an Effective Pretreatment Process to Break Microalgal Cell Wall and Enhance Algal Oil Extraction. Foods. 10, 1928. doi:10.3390/foods10081928

Blanco-Llamero, C., and Señoráns, F. J. (2021). Biobased Solvents for Pressurized Liquid Extraction of Nannochloropsis Gaditana Omega-3 Lipids. Mar. Drugs. 19, 107. doi:10.3390/md19020107

Bradford, M. M. (1976). A Rapid and Sensitive Method for the Quantitation of Microgram Quantities of Protein Utilizing the Principle of Protein-Dye Binding. Anal. Biochem. 72, 248-254. doi:10.1006/abio.1976.9999
Funding: acquisition: FS. All authors have read and agreed to the published version of the manuscript.

\section{FUNDING}

This research was funded by the Comunidad de Madrid (Spain) through project ALGATEC-CM (P2018/BAA-4532), co-financed by the European Social Fund.

\section{ACKNOWLEDGMENTS}

The authors gratefully acknowledge the support from the CYTED network RENUWAL (project 320RT0005). The authors are also grateful to Novozymes and Cianoalgae (Madrid, Spain) for generously donating the commercial enzymes and Nannochloropsis gaditana biomass samples, respectively.

Castejón, N., Luna, P., and Señoráns, F. J. (2018). Alternative Oil Extraction Methods from Echium plantagineum L. Seeds Using Advanced Techniques and Green Solvents. Food Chem. 244, 75-82. doi:10.1016/ j.foodchem.2017.10.014

Castejón, N., and Señoráns, F. J. (2019). Simultaneous Extraction and Fractionation of Omega-3 Acylglycerols and Glycolipids From Wet Microalgal Biomass of Nannochloropsis Gaditana Using Pressurized Liquids. Algal Res. 37, 74-82. doi:10.1016/j.algal.2018.11.003

Castejón, N., and Señoráns, F. J. (2020). Enzymatic Modification to Produce Health-Promoting Lipids From Fish Oil, Algae and Other New Omega-3 Sources: A Review. New Biotechnol. 57, 45-54. doi:10.1016/j.nbt.2020.02.006

Chen, Q., Liu, D., Wu, C., Xu, A., Xia, W., Wang, Z., et al. (2017). Influence of a Facile Pretreatment Process on Lipid Extraction from Nannochloropsis Sp. Through an Enzymatic Hydrolysis Reaction. RSC Adv. 7 (84), 53270-53277. doi:10.1039/c7ra11483d

Chen, Q., Liu, D., Wu, C., Yao, K., Li, Z., Shi, N., et al. (2018). CoImmobilization of Cellulase and Lysozyme on Amino-Functionalized Magnetic Nanoparticles: An Activity-Tunable Biocatalyst for Extraction of Lipids From Microalgae. Bioresour. Technology. 263 (May), 317-324. doi:10.1016/j.biortech.2018.04.071

Dixon, C., and Wilken, L. R. (2018). Green Microalgae Biomolecule Separations and Recovery. Bioresour. Bioproc. 5, 1. doi:10.1186/s40643-018-0199-3 
Folch, J., Lees, M., and Stanley, G. H. S. (1957). A Simple Method for the Isolation and Purification of Total Lipides From Animal Tissues. J. Biol. Chem. 226 (1), 497-509. doi:10.1016/s0021-9258(18)64849-5

Gao, S., Rojas-Vega, F., Rocha-Martin, J., and Guisán, J. M. (2021). Oriented Immobilization of Antibodies through Different Surface Regions Containing Amino Groups: Selective Immobilization Through the Bottom of the Fc Region. Int. J. Biol. Macromolecules. 177, 19-28. doi:10.1016/j.ijbiomac.2021.02.103

García-García, P., Fernandez-Lorente, G., and Guisan, J. M. (2021). Capture of Enzyme Aggregates by Covalent Immobilization on Solid Supports. Relevant Stabilization of Enzymes by Aggregation. J. Biotechnol. 325, 138-144. doi:10.1016/j.jbiotec.2020.11.006

Gong, M., and Bassi, A. (2016). Carotenoids From Microalgae: A Review of Recent Developments. Biotechnol. Adv. 34 (8), 1396-1412. doi:10.1016/j.biotechadv.2016.10.005

Guajardo, N., Ahumada, K., and Domínguez de María, P. (2021). Immobilization of Pseudomonas Stutzeri Lipase Through Cross-Linking Aggregates (CLEA) for Reactions in Deep Eutectic Solvents. J. Biotechnol. 337, 18-23. doi:10.1016/ j.jbiotec.2021.06.021

Hero, J. S., Morales, A. H., Perotti, N. I., Romero, C. M., and Martinez, M. A. (2020). Improved Development in Magnetic Xyl-CLEAs Technology for Biotransformation of Agro-Industrial By-Products Through the Use of a Novel Macromolecular Cross-Linker. Reactive Funct. Polym. 154, 104676. doi:10.1016/j.reactfunctpolym.2020.104676

Katiyar, R., and Arora, A. (2020). Health Promoting Functional Lipids From Microalgae Pool: A Review. Algal Res. 46, 101800. doi:10.1016/j.algal.2020.101800

Kimberle, P. d. S., Carolina, M.-S., Ana, I. S. B., and Luciana, R. B. G. (2020). Modifying Alcalase Activity and Stability by Immobilization onto Chitosan Aiming at the Production of Bioactive Peptides by Hydrolysis of tilapia Skin Gelatin. Process Biochem. 97, 27-36. doi:10.1016/j.procbio.2020.06.019

Mahdy, A., Mendez, L., Ballesteros, M., and González-Fernández, C. (2014). Enhanced Methane Production of Chlorella Vulgaris and Chlamydomonas Reinhardtii by Hydrolytic Enzymes Addition. Energ. Convers. Management. 85, 551-557. doi:10.1016/j.enconman.2014.04.097

Perwez, M., Mazumder, J. A., Noori, R., and Sardar, M. (2021). Magnetic Combi CLEA for Inhibition of Bacterial Biofilm: A Green Approach. Int. J. Biol. Macromolecules. 186, 780-787. doi:10.1016/j.ijbiomac.2021.07.091

Poorakbar, E., Shafiee, A., Saboury, A. A., Rad, B. L., Khoshnevisan, K., Ma’mani, L., et al. (2018). Synthesis of Magnetic Gold Mesoporous Silica Nanoparticles Core Shell for Cellulase Enzyme Immobilization: Improvement of Enzymatic Activity and thermal Stability. Process Biochem. 71, 92-100. doi:10.1016/ j.procbio.2018.05.012

Punia, S., Sandhu, K. S., Siroha, A. K., and Dhull, S. B. (2019). Omega 3Metabolism, Absorption, Bioavailability and Health Benefits-A Review. PharmaNutrition. 10, 100162. doi:10.1016/j.phanu.2019.100162

Romero, O., Guisán, J. M., Illanes, A., and Wilson, L. (2012). Reactivation of Penicillin Acylase Biocatalysts: Effect of the Intensity of Enzyme-Support Attachment and Enzyme Load. J. Mol. Catal. B: Enzymatic. 74, 224-229. doi:10.1016/j.molcatb.2011.10.009

Romero-Fernández, M., Moreno-Perez, S., H. Orrego, A., Martins de Oliveira, S., I. Santamaría, R., Díaz, M., et al. (2018). Designing Continuous Flow Reaction of Xylan Hydrolysis for Xylooligosaccharides Production in Packed-Bed Reactors Using Xylanase Immobilized on Methacrylic Polymer-Based Supports. Bioresour. Technology. 266, 249-258. doi:10.1016/j.biortech.2018.06.070

Safi, C., Olivieri, G., Campos, R. P., Engelen-Smit, N., Mulder, W. J., van den Broek, L. A. M., et al. (2017). Biorefinery of Microalgal Soluble Proteins by Sequential Processing and Membrane Filtration. Bioresour. Technology. 225, 151-158. doi:10.1016/j.biortech.2016.11.068
Sánchez-Bayo, A., Morales, V., Rodríguez, R., Vicente, G., and Bautista, L. F. (2019). "Biodiesel Production (FAEEs) by Heterogeneous Combi-Lipase Biocatalysts Using Wet Extracted Lipids From Microalgae. Catalysts. 9, 296. doi:10.3390/catal9030296

Señoráns, M., Castejón, N., and Señoráns, F. J. (2020). Advanced Extraction of Lipids with DHA From Isochrysis galbana with Enzymatic Pre-Treatment Combined With Pressurized Liquids and Ultrasound Assisted Extractions. Molecules. 25 (14), 3310. doi:10.3390/molecules25143310

Sheldon, R. (2019). CLEAs, Combi-CLEAs and 'Smart' Magnetic CLEAs: Biocatalysis in a Bio-Based Economy. Catalysts. 9, 26. doi:10.3390/catal9030261

Velasco-Lozano, S. (2020). Immobilization of Enzymes as Cross-Linked Enzyme Aggregates: General Strategy to Obtain Robust Biocatalysts. Methods Mol. Biol. 2100, 345-361. doi:10.1007/978-1-0716-0215-7_23

Wang, Q., Xie, Y., Johnson, D. R., Li, Y., He, Z., and Li, H. (2019). Ultrasonic-Pretreated Lipase-catalyzed Synthesis of Medium-Long-Medium Lipids Using Different Fatty Acids as Sn -2 Acyl-Site Donors. Food Sci. Nutr. 7 (7), 2361-2373. doi:10.1002/fsn3.1083

Xu, M., Ji, D., Deng, Y., and Agyei, D. (2020). Preparation and Assessment of CrossLinked Enzyme Aggregates (CLEAs) of $\beta$-Galactosidase From Lactobacillus Leichmannii 313. Food Bioproducts Process. 124, 82-96. doi:10.1016/j.fbp.2020.08.004

Yen, H.-W., Hu, I.-C., Chen, C.-Y., Ho, S.-H., Lee, D.-J., and Chang, J.-S. (2013). Microalgae-Based Biorefinery - From Biofuels to Natural Products. Bioresour. Technology. 135, 166-174. doi:10.1016/j.biortech.2012.10.099

Zhang, R., Chen, J., and Zhang, X. (2018a). Extraction of Intracellular Protein From Chlorella Pyrenoidosa Using a Combination of Ethanol Soaking, Enzyme Digest, Ultrasonication and Homogenization Techniques. Bioresour. Technology. 247, 267-272. doi:10.1016/j.biortech.2017.09.087

Zhang, W., Leong, S. M., Zhao, F., Zhao, F., Yang, T., and Liu, S. (2018b). Viscozyme L Pretreatment on Palm Kernels Improved the Aroma of palm Kernel Oil After Kernel Roasting. Food Res. Int. 107, 172-181. doi:10.1016/j.foodres.2018.02.023

Zhang, T.-T., Xu, J., Wang, Y.-M., and Xue, C.-H. (2019). Health Benefits of Dietary Marine DHA/EPA-Enriched Glycerophospholipids. Prog. Lipid Res. 75, 100997. doi:10.1016/j.plipres.2019.100997

Zhang, W., Zhao, F., Yang, T., Zhao, F., and Liu, S. (2017). Celluclast 1.5L Pretreatment Enhanced Aroma of Palm Kernels and Oil After Kernel Roasting. J. Sci. Food Agric. 97 (15), 5146-5157. doi:10.1002/jsfa.8394

Zuorro, A., Maffei, G., and Lavecchia, R. (2016). Optimization of Enzyme-Assisted Lipid Extraction From Nannochloropsis Microalgae. J. Taiwan Inst. Chem. Eng. 67, 106-114. doi:10.1016/j.jtice.2016.08.016

Conflict of Interest: The authors declare that the research was conducted in the absence of any commercial or financial relationships that could be construed as a potential conflict of interest.

Publisher's Note: All claims expressed in this article are solely those of the authors and do not necessarily represent those of their affiliated organizations or those of the publisher, the editors, and the reviewers. Any product that may be evaluated in this article, or claim that may be made by its manufacturer, is not guaranteed or endorsed by the publisher.

Copyright (® 2021 Blanco-Llamero, García-García and Señoráns. This is an openaccess article distributed under the terms of the Creative Commons Attribution License (CC BY). The use, distribution or reproduction in other forums is permitted, provided the original author(s) and the copyright owner(s) are credited and that the original publication in this journal is cited, in accordance with accepted academic practice. No use, distribution or reproduction is permitted which does not comply with these terms. 